\title{
Talent Management in SMEs: An Exploratory Study of Polish Companies
}

\author{
Urban Pauli, Aleksy Pocztowski
}

\section{A B S T R A C T}

Objective: The main goal of the study is to identify and map practices of TM in SMEs and search for common patterns. The main questions during the design of the research were: How do SMEs define talent and what are its indicators? What is the approach to TM in SMEs? What kind of activities relating to TM do SMEs undertake? Is it possible to link activities undertaken by SMEs in coherent patterns?

Research Design \& Methods: This exploratory study was conducted on a randomly selected 200 Polish SMEs. After collecting the sample, we employed the CAPI technique. Most of the questions were open-ended and multiple-choice. In the analysis, we used data clustering and descriptive statistics.

Findings: The research confirms that talent management in SMEs occurs in various ways, while particular approaches differ significantly. However, taking into account such categories as talent indicators, main activities undertaken, talents' tasks and roles, we can identify some common patterns.

Implications \& Recommendations: The main implication is that a variety of approaches to TM in SMEs requires the application of a contextual framework, which should include the specificity of both internal and external factors. We recommend SMEs' owners and managers define the main aim of introducing TM practices and shape them in a way that allows fulfilling expected outcomes.

Contribution \& Value Added: This paper addresses three main research gaps. By presenting data gathered from 200 SMEs we refer to a call for empirically grounded studies. By conducting cluster analysis and developing a model, we refer to the lack of conceptual frameworks of TM in SMEs. Finally, we address a call for more context-specific research by presenting data on TM practices in Polish SMEs.

Article type: research article

Keywords: $\quad$ talent; talent management; SMEs; human resource management JEL codes: M51, M54

Received: 2 October 2019 Revised: 14 November 2019 Accepted: 16 November 2019

\section{Suggested citation:}

Pauli, U., \& Pocztowski, A. (2019). Talent Management in SMEs: An Exploratory Study of Polish Companies. Entrepreneurial Business and Economics Review, 7(4), 199-218. https://doi.org/10.15678/EBER.2019.070412 


\section{INTRODUCTION}

Talent management (TM) is a dynamically developing field of research, proven by a number of publications and findings that describe the current understanding of this area (Al Ariss, Cascio, \& Paauwe, 2014; Collings, 2014; Morley, Scullion, Collings, \& Schuler, 2015; McDonnell, Collings, Mellahi, \& Schuler, 2017). Most literature that reviews articles continuously raises two issues. The first refers to the underrepresentation of empirically grounded research (McDonnell et al., 2017); the second indicates the insufficient consideration of contextual issues (Lewis \& Hackman, 2006; Collings \& Mellahi, 2009; Dries, 2013a; Dries, 2013b; Al Ariss et al., 2014). The application of a contextual framework can be of the highest importance when analysing TM processes in small and medium-sized enterprises (SMEs). According to Krishnan and Scullion (2017), "the notion of talent management is not replicable to SMEs and the conceptualisation of TM as proposed for large firms needs adaptation in the SME context. SMEs experience a greater degree of instability in their structural forms and management processes" (p. 432). Moreover, as Festing Harsch, Schäfer, and Scullion (2017) indicate, "there is need for theoretical perspectives and conceptual developments to increase understanding in TM area, and more generally to explain why talent management in SMEs differs from that in large organizations" (p. 488). Festing et al. (2017) attend to three issues: the challenges of TM in SMEs in the context of the labour market, the understanding of talent in SMEs, and the differences in the TM system with regard to cultural differences in particular countries. Despite the fact that they identify such research gaps, the majority of research concerning TM studies large or multinational enterprises (MNEs), leaving TM practices in SMEs insufficiently investigated.

This paper contributes to the debate on TM by addressing three main research gaps raised in the literature. Firstly, by presenting data gathered from 200 SMEs, we provide more detailed information concerning talent management practices in SMEs. Secondly, by conducting cluster analysis and developing a theoretical model of TM in SMEs, we refer to the lack of conceptual frameworks of TM in SMEs. Our findings are grounded in empirical research and are built on the basis of identified actions undertaken by SMEs. Thirdly, by presenting data of TM practices in Polish SMEs - the sixth largest country in the EU population-wise (Eurostat, 2018) - we respond to the call for more context specific research. Moreover, this paper discusses alternative approaches to TM - those developed in SMEs - and presents a conceptual framework of talent management approaches in SMEs, which may widen the theoretical discussion about the boundaries of the phenomenon. Moreover, we present the SME owner/manager perspective while mapping talent management practices. Such a viewpoint is rarely investigated, as most research assumes the perspective of the HR manager or specialist.

In our research, we assume that SMEs do not implement solutions and best practices developed in large companies (often MNEs). The rationale for such an assumption stems from three predictors. Firstly, SMEs in general do not have HR departments responsible for executing HR functions. Secondly, SMEs suffer from limited resources, which results in reducing or optimising supportive functions, also HR departments (Price, 2004; Patel \& Cardon, 2010; Razouk, 2011; Pocztowski \& Pauli, 2013). Thirdly, HR activities in many SMEs are executed by owners or managers, who may not have developed the required level of competence required for designing TM. As a result, 
such enterprises may develop different TM practices, which are highly related to the context in which they operate and to resources they have.

This article is divided into three sections. The first consists of a literature review referring to TM, TM in the context of Poland and TM in SMEs. In the second section, the methodology and results of our research are presented; this is followed by a discussion of the findings with regard to previous research and theory.

\section{LITERATURE REVIEW}

\section{Talent Management in Organisations}

Although there are many papers about TM, the definition of talent is still an issue that needs consideration. Talent definition is constantly discussed whether talent is innate or acquired and whether the designation of talent should be based on potential or performance (Thunnissen, Boselie, \& Fruytier, 2013; Morley et al., 2015). The complexity of these issues is coherently presented by Dries (2013b), who indicates that the definition of talent can include six perspectives: talent as capital, talent as individual difference, talent as giftedness, talent as identity, talent as strength, and talent as the perception of talent. Moreover, according to Gallardo-Gallardo, Dries, and Gonzalez-Cruz (2013), talent is often equated to excellent performance or to unique or above-average skills and abilities. On the basis of the literature review, they identify approaches to talent that refer to talent as a natural ability, mastery of systematically developed skills, commitment and motivation, fit between an individual's 'talent' and the work context (Gallardo-Gallardo et al., 2013).

Recent studies mostly concentrate on referring to strategic positions, jobs, or roles. These studies analyse talent in reference to positions that have a direct and explicit impact on a firm's performance and can, thus, be regarded as pivotal (Collings, 2014). Due to such an understanding, Cappelli and Keller (2014) suggest including high performing (HP) and high potential ( $\mathrm{HiPo}$ ) candidates in the group of those that fulfil strategic jobs. A similar understanding of talent appears in Becker and Huselid (2006), they argue that the value of talented employees depends on the position they occupy. The consideration of roles that these talented employees occupy enables the classification of all employees with regard to the effects a particular employee or job can produce (Huselid \& Becker, 2011). Thus, it is very important to identify pivotal positions within the organisation. Such an approach agrees with the findings of Collings and Mellahi (2009), who argue that organisations should differentiate employees regarding tasks they fulfil or positions they occupy. They indicate that pivotal positions or jobs should be filled by high performers with high potential. According to Cappelli and Keller (2014), such a differentiation refers to the historical view of TM, which assumes that strategic jobs are related to executive positions. Due to changes in the business environment and the flattening of organisational structures or their organisation around processes, pivotal jobs and managerial positions no longer have to be mutually inclusive.

Despite the fact that talent management can be classified with the use of different criteria, the findings of Collings and Mellahi (2009) outline four different approaches to talent management - people, practices, position, and strategic pools approach - which highly reflects the scope and aims of the research conducted in the field. On the basis of these approaches, Iles, Chuai, and Preece (2010) propose a four-square model. They divide 
TM programmes implemented in MNEs by taking into account two dimensions: orientation on people (PE) versus position (PO); exclusiveness (E) versus inclusiveness (I). The developed model consists of four approaches: (1) key individuals or 'stars' (PE-E); (2) everyone has a talent and potential (PE-I); (3) social capital development in pivotal positions (PO-I); (4) the right people to fill key positions (PO-E).

Collings and Mellahi's $(2009$, p. 304$)$ research results led to the development of a coherent definition of TM as:

"activities and processes that involve the systematic identification of key positions which differentially contribute to the organisation's sustainable competitive advantage, the development of a talent pool of high potential and high performing incumbents to fill these roles, and the development of a differentiated human resource architecture to facilitate filling these positions with competent incumbents and to ensure their continued commitment to the organization".

Activities and processes indicated in the definition should concern talent acquisition, identification, selection, development, remuneration, retention, and career planning (Boxall \& Macky, 2009; Nijs, Gallardo-Gallardo, Dries, \& Sels 2014; Morley et al., 2015). According to Collings and Mellahi (2009) the identification of pivotal positions should be the first step in the design and implementation of talent management systems, because it enables the identification of HPs and HiPos who are the potential participants of such TM programmes. Moreover, Boudreau and Ramstad (2004) state that actions connected with TM should be considered in terms of three elements: impact, effectiveness, and efficiency.

We may conclude that TM consist of advanced schemes and practices aimed at building employer branding, attracting candidates, selecting those with the highest potential or identifying them within the organisation - creating appropriate working conditions that enhance creativity (Ingram, 2016), providing developmental programmes, and motivating and remunerating talented employees in accordance with the added value that they create. TM programmes not only enable the use of competences that employees already have but also focus organisations on creating new knowledge, developing skills, and building attitudes that are (or may be) crucial for achieving strategic goals.

\section{The Polish Context of Talent Management}

Talent management in Poland is a rapidly growing field of scientific research, but also a central interest of many HR managers and specialists. Approaches to TM in Polish companies are mainly determined by two factors. The first refers to the change in HRM, which started three decades ago, while the second to the labour market dynamics.

After the collapse of command economy, the HR approach in Polish companies significantly changed. Undoubtedly, MNEs played a crucial role in the transformation of HR in Poland. The shift occurred due to both FDI and the arrival of foreign managers in leadership positions, which resulted in the implementation of Western European and North American business models. The new situation caused the inclusion of strategic HRM in companies and the removal of egalitarianism, which implies the implementation of more diversified reward systems. Thus, high performers started to play an important role in assuring business outcomes (Morley, Poor, Heraty, Alas, \& Pocztowski 2016). This change increased the interest in managing particular groups of employees, one of which is tal- 
ented workers (Miś, 2011). TM programmes implemented at the initial stage of HR development in Poland were strongly based on foreign solutions, as there previously were no Polish approaches, models, and processes in this regard. Foreign solutions partly corresponded to the Polish context, in which employees are generally characterised as having a "high level of uncertainty avoidance, a middle level of power distance, individualism, masculinity, inner control, are traditionalists rather than secular-rationalists, and mostly survival-oriented, emphasising economic and physical security rather than focusing on self-expression and quality of life" (Listwan, Pocztowski, \& Stor, 2009, p. 103). Moreover, in the 1990s and the early 2000s, the attitude of Polish workers to work was influenced by the expectation of high development and achievements, which was raised on the basis of new opportunities offered by the political transition and, later, the accession to the European Union. Such a change in attitudes was a perfect foundation for the implementation of TM programmes. As for now, HR practices are still strongly influenced by solutions developed in other countries, as Poland is at third place in the world rank "a new place for SSC" (Deloitte, 2017), and new SSC branches open every year.

The second factor that impacts approaches to TM refers to labour market dynamics. After the transition and implementation of new regulations in the 1990s, the proportion of unemployed people in Poland was rising. In 2001, the unemployment rate reached $17.4 \%$, which was the highest in Europe. In 2003, unemployment stood at $20.1 \%$. The share of Poles with higher education simultaneously increased from 2\% in 1990 to $12 \%$ in 2004 (Listwan et al., 2009). As a result of these factors, many companies were able to hire employees with high levels of competence and motivation. Thus, HR managers and specialists focused on implementing detailed multistage practices for selecting candidates, because the number of applications allowed them to choose the highest potentials. However, in many cases, employees were overeducated with regard to the tasks they were to fulfil.

After the accession to the EU in 2004, many international employment agencies were set up in western countries to serve companies that wished to hire Poles, as they were perceived as professional, responsible, creative, and hard-working (Listwan et al., 2009). However, many Polish companies simultaneously complained that Poland suffers from brain drain, as many workers migrated to Western countries (the unemployment rate decreased from $20 \%$ in 2004 to $9.5 \%$ in 2008). This caused companies to start paying more attention to talent development and retention in order to prevent turnover.

Currently, Polish companies face many difficulties with hiring employees. The unemployment rate in June 2018 was at 5.9\%, but in large cities the shortage of candidates especially those highly qualified - is starkly noticeable; the situation effects SMEs in particular. Their share in the total employment is at $30 \%$ and - according to Statistics Poland - they have recently increased investments in talent development. This causes SMEs to seek new employees, but they spend less on employer branding and are perceived as offering worse working conditions than larger companies. This makes SMEs pay more attention to attracting valuable candidates and retain those who are already employed.

The emerging and rapidly growing interest of Polish companies in TM is reflected in the number of scientific research and publications. In 2006, a report on TM in Poland was published by The Conference Board with results of empirical research. Until now, numerous articles and some textbooks appeared that present approaches and practices of TM in Poland (e.g. Borkowska, 2005; Pocztowski, 2008; Ingram, 2011; Miś, 2011; Tabor, 2013; 
Skuza, 2018), some of them with the cooperation of foreign researchers (e.g. Skuza, Scullion, \& McDonnell, 2013; Waters-Sobkowiak, Kowalski, \& Smits, 2018). However, there are no publications that directly refer to TM in SMEs.

\section{Talent Management in SMEs}

The results of Rauch and Hatak's (2016) research may be used as the starting point for analysing HRM practices in SMEs. They find a positive cause and effect relationship between HRM activities and performance. Moreover, they argue that such a relationship can be stronger in SMEs than in larger companies. Similar conclusions were raised by Vlachos (2009) who compares HR practices at consecutive stages of SMEs growth. Vlachos finds that HR activities are correlated with sales growth, performance, and market share. Moreover, the positive relationship between HR practices and SME performance finds support in other studies (Patel \& Cardon, 2010; Razouk, 2011; Sheehan, 2014). Thus, we may conclude that the potential of SMEs to achieve a sustainable and competitive advantage depends on the quality of HR processes. Such a relationship stems from the importance of human capital, which can be characterised by the VRIN attributes: valuable, rare, inimitable, nonsubstitutable (Barney, 1991).

Although scholars traced the relationship between HR and SME performance, there are difficulties in developing a common approach to HRM activities in SMEs, which may stem from four factors. Firstly, most of these companies apply different and unique patterns of executing personnel functions as their business models and the environment in which they operate differ. Secondly, according to Cardon and Stevens (2004), SMEs suffer from limited resources, which results in optimising or even reducing HR processes. Thirdly, implementing HR practices for large companies may require changes in organisational structures, which can be considered too expensive for many SMEs (Patel \& Cardon, 2010). Lastly, solutions developed in large companies are not suitable for SMEs, because there are no HR departments in such organisations. SMEs run standard HR processes by referring to recruitment, appraisal, training, and remuneration (Cardon \& Stevens, 2004), but they are organised in a different way. These processes are executed mostly by managers and owners who are not prepared to run them due to the lack of required competences. They are specialists in the main field of the firm's business, but they frequently suffer from insufficient managerial skills (Price, 2004; Razouk, 2011; Pocztowski \& Pauli, 2013). Thus, according to Westhead and Storey (1996), we may conclude that SMEs are not a "scaleddown" version of a large company, so processes implemented in SMEs are designed in a different manner to meet their specific needs and operating models.

Although scholars investigate TM for three decades already, their research mainly focuses on large companies, without enough attention to the characteristics of SMEs (Boudreau \& Ramstad, 2004; Scullion, Collings, \& Caliguiri, 2010; Tarique \& Schuler, 2010; Vaiman \& Holden, 2011; Festing, Schafer, \& Scullion, 2013; Valverde, Scullion, \& Ryan, 2013; Collings, 2014; Festing et al., 2017; Sparrow \& Makram, 2015). Due to the variety of approaches to HR management that SMEs apply, they may implement TM processes that significantly differ from those suitable for large companies. Although the scope of TM activities and processes in SMEs may be similar to those implemented in MNEs, this seems to be all they have in common. It would be difficult or even impossible to replicate already developed models (Festing et al., 2013; Krishnan \& Scullion, 2017). Thus, mapping TM patterns in SMEs requires the inclusion of the environmental context, which consists of both 
internal and external factors (Gallardo-Gallardo, Thunnissen, \& Scullion, 2017; Krishnan \& Scullion, 2017). Moreover, as Festing et al. (2013), Skuza et al. (2013), and Valverde et al. (2013) indicate, the approach to TM in SMEs may differ with regard to country-specific cultural context. While designing TM in SMEs, we should account for some specified practices by referring to the uniqueness of undertaken actions and initiatives (Joyce \& Slocum, 2012; Krishnan \& Scullion, 2017). Moreover, the approach to TM may vary in accordance with the stage of SME growth (Krishnan \& Scullion, 2017). The importance of particular resources at consecutive stages can change, which means that the share of investments in human capital can differ (Pauli, 2015). Moreover, as concluded by Valverde et al. (2013), many SME owners are unaware of the concept of TM, even though they undertake actions that can be regarded as part of TM programmes. The authors observe a tendency among SMEs to defer the formalisation of the concept of TM (Valverde et al., 2013).

Taking into account the complexity of such programmes, we should state that these programmes can be structured in various ways in SMEs. We may draw some general findings concerning the TM approach in SMEs on the basis of the research conducted by Valverde et al. (2013): (1) there is a greater emphasis on performance rather than potential while defining talent; (2) employees identified as talents can occupy managerial, key, or standard positions; (3) the key features of talents refer not only to knowledge and skills but also to attitudes that present personal allegiance to the company; (4) both the inclusive and exclusive approach to talents is applied; (5) in general, the same HR systems are used for talented and non-talented personnel, but some distinction can be made with regard to the scope of training, decision-making and access to information; (6) talents occupy key positions or are perceived as successors. Such a finding confirms that the approaches to TM in SMEs may vary, and there are significant difficulties in creating a coherent model to describe actions undertaken in such organisations. However, on the basis of the research conducted on German SMEs, Festing et al. (2013) identify three clusters that refer to TM approach in SMEs: "highly engaged talent management" means companies that apply a variety of TM practices continuously; "reactive talent management" indicates companies that focus on HR planning with little investment in training and employee retention; "retentionbased talent management" defines companies that focus on training, development, succession, and career planning to prevent the turnover of valuable employees.

Therefore, we may conclude that the approaches and patterns of SMEs to TM received insufficient scholarly attention. Moreover, the results of the above studies show that the complexity of actions undertaken in SMEs can lead to the development of more than one model, as the context of SMEs operations makes them vary. In our research, we assumed that a talented person in SMEs can be defined in a broader sense, as an employee who occupies either managerial or non-managerial positions and (1) achieves above-average performance in a certain domain, (2) has high potential, (3) presents a willingness to develop, and (4) is eager to take on responsibilities for pivotal tasks and roles. When defining the potential, we consider employee competences, which consist of knowledge, skills, attitudes, and abilities (Boyatzis, 1982; Spencer \& Spencer, 1993). Such an approach agrees with Luna-Arocas and Morley (2015) who conclude that TM is associated with competency-based management. Moreover, they argue that talent competences should be appropriate to a work context, which directly refers to the contextual-related competency framework (Sandberg \& Pinnington, 2009). 


\section{MATERIAL AND METHODS}

\section{Research Goals and Questions}

The main goal of the study was to identify and map TM practices in SMEs and seek their common patterns. As highlighted in the literature review section, SMEs may undertake different actions aimed at maximising the use of human capital. These actions depend on the characteristics of SMEs, the context in which they operate, and the resources they have. Moreover, in contrast to larger companies, SMEs very often have no HR departments (or even positions) responsible for executing HR tasks, especially those which are not comprehensive enough to be involved in activities such as TM. This means that in many SMEs, TM may not run systematically and the scope of actions significantly differs from those implemented in large companies. Thus, the main questions we asked when designing our research were: How do SMEs define talent and with what indicators? What is the approach to TM in SMEs? What kind of activities relating to TM do SMEs undertake? Is it possible to link activities undertaken by SMEs into coherent patterns? In our research, we assumed that - although there are significant differences in approaches to TM among SMEs - there appear some commonalities. These features can form the foundations for developing a model for defining TM in SMEs.

\section{Measures Applied}

Talent indicators describe the way owners or managers perceive talent. It may refer to: above-average performance, specific knowledge, skills, abilities, attitudes, unique experience in a particular field, or impact/influence of a talent on other employees. Such understanding refers to approaches discussed by Dries (2013b), Gallardo-Gallardo et al. (2013), Valverde et al. (2013).

Approaches to TM refer to the way SMEs organise TM, particularly whether it is executed systematically or occasionally, and whether it is exclusive or inclusive (Iles et al., 2010; Festing et al., 2013; Al Ariss et al., 2014).

The scope of TM describes SMEs' actions to manage talent. On the basis of the literature review, we included the following activities: talent acquisition, identification, selection, development, appraisal, remuneration, and career planning (Boxall \& Macky, 2009; Valverde et al., 2013; Nijs et al., 2014; Morley et al., 2015).

The scope of talent tasks and roles refers to talents' positions and their duties. It enables the identification whether a talent is hired on managerial or non-managerial positions, and whether they have responsibilities for (1) tasks directly connected with their post, (2) tasks related to owned competences, (3) specialised tasks in a particular domain, (4) coordination, or (5) support of managerial decisions (Collings \& Mellahi, 2009; Becker \& Huselid, 2006; Valverde et al., 2013; Cappelli \& Keller, 2014; Collings, 2014).

\section{Methods and Analytical Procedure}

Our research used the database of Statistics Poland. The first step in sampling was to verify whether TM is introduced in a particular SME. This is why the selected number of companies was contacted via telephone and asked if they run actions aimed at talent management. Those who confirmed were asked if they would take part in the research. 
Such an approach made it possible to investigate only the companies aware of TM, who applied specific actions. However, according to Valverde et al. (2013), such sampling excludes the companies who may run TM but are unaware of it or defer from formalising the concept. After collecting the sample, we employed the CAPI technique in research and interviewed owners or managers. Interviewers used a questionnaire comprising three main sections. The first section covered issues connected with the context in which SMEs operate. The second section aimed at collecting information about actions undertaken to manage talents. The third section asked the interviewees to evaluate trends in performance indicators referring to their business. In this article, we only use the data that referred to the understanding of talent and describing the characteristics of TM. To obtain this data, interviewees were asked the following: (1) Who is talented and what are talent indicators? (2) How do you organise activities referring to TM? (3) Which of the processes are covered by TM: talent identification, acquisition, training and development, remuneration, evaluation, career planning, teambuilding, employer branding? (4) Which of the techniques are used in each of these processes? (5) Which positions do talents occupy, and what is the scope of their activities? (6) To what extent do you account for the talent's expectations concerning working conditions? All questions were open-ended and multiple-choice, which allowed us to evaluate the level of application of theoretically grounded practices and capture distinct actions undertaken by a particular company. The average interview lasted thirty minutes.

In the first step of analysis we used the Ward method, aimed at estimating the number of possible clusters. We used the following raw data in the clustering: talent indicators, approach to TM, scope of particular TM processes and actions undertaken, talents' tasks and roles, level of talents' expectations (concerning work conditions), inclusion. All SMEs were divided into six clusters with the use of the $k$-means method (Sokołowski \& Czaja, 2014; Hartigan \& Wong, 1979). The next stage of the analysis was to calculate descriptive statistics for each variable in particular clusters. A synthesis of the analysis obtained when characterising each cluster appears in the Results section and is summarised in Table 2.

\section{RESULTS}

\section{Sample Characteristics}

The research was conducted on a randomly selected group of 200 SMEs that operate in Poland. Following the definition by the European Commission, we included companies that had 10-250 employees. In the research, only SMEs which reported the introduction of specified actions aimed at managing talents were included. The basic characteristics of the sample are presented in Table 1.

On the basis of $k$-means clustering, we identified six clusters following talent indicators, approach to TM, main activities undertaken by SMEs, and talents' tasks and roles. The features of each cluster with regard to descriptive characteristics are presented in the following section. 
Table 1. Sample characteristics (in \%)

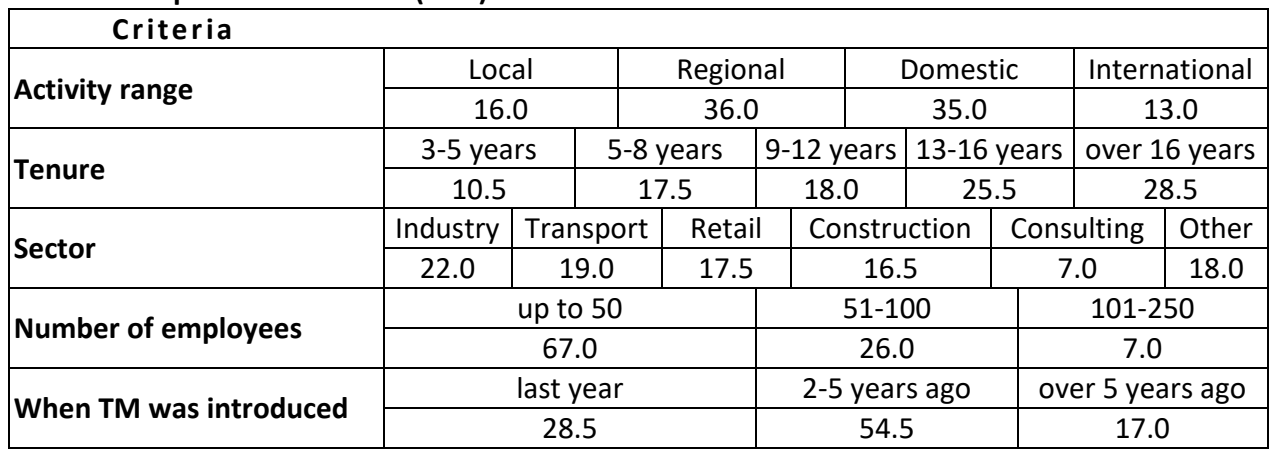

Source: own study.

\section{Clusters Characteristics}

\section{C1: High Performance Manager ( $\mathrm{N}=30)$}

In most of these companies, talents mean high performers (83\%). TM can be both inclusive (in $40 \%$ of SMEs in this cluster) or exclusive (30\%) while TM actions are run systematically. The main activity undertaken in TM is talent identification (63\%) and training (43\%). To identify talents, most of these SMEs (65\%) analyse long-term performance over a period of a few years; $35 \%$ of SMEs only evaluate the achievement of previous yearly goals. In order to acquire talents, most companies publish job advertisements in various media, but they set very high requirements to attract only the best candidates (80\%). In the selection process, a standard interview is most commonly used (63\%), but case studies directly related to tasks on a given job position are also applied. The talents' roles and tasks can also be directly related to their competences and qualifications (77\%). These companies may introduce tailored training programmes for talents (70\%) aimed at developing managerial competences (80\%). Such programmes mostly consist of internal training conducted by trainers or specialists employed in the firm in $60 \%$ of cases, general training (50\%), and firm-tailored training conducted by external trainers (47\%). SMEs from this cluster implement specific forms of remuneration of talents (87\%) including differentiation in rewards, bonuses, and other forms of remuneration; appraisal (80\%) including differentiation in criteria and techniques; career planning (77\%) including building personalised career paths and enabling the development of one's passions and interests. While designing TM, all of these companies (100\%) account for the expectations of talents they refer to: motivational systems, remuneration, training needs, and career paths. Moreover, most companies include demands of promotion (93\%), tasks or challenges (97\%), and autonomy (93\%).

\section{C2: High Performance Specialist $(\mathrm{N}=31)$}

In this cluster, performance (55\%) and the ability to fulfil a wide scope of tasks (48\%) are most frequently highlighted as talent indicators. Companies in this cluster do not introduce a coherent TM system. Some run systematic TM for all employees (26\%), but others take differentiated, actions (22\%). The main activity is talent acquisition (58\%) and identification (45\%). To conduct the identification of talent, SMEs must include performance evaluation referring to the previous year $(36 \%)$ or the previous few years $(36 \%)$. For the 
purposes of talent recruitment, most of these SMEs (90\%) use standard job advertisements and hire candidates who may be defined as talents. Moreover, $29 \%$ of companies claim to use employee referrals. In the selection process, basic techniques are generally used: $94 \%$ run screening and $87 \%$ conduct job interviews. Talents are responsible for fulfilling tasks directly related to their qualifications (in $52 \%$ of companies in this group). In $87 \%$ of cases, there is no specific training offered to talents, they attend the same development programmes as other employees. In $90 \%$ of cases, this training is aimed at increasing the level of skills required for tasks fulfilment. The most commonly applied training methods are generally available training (77\%), courses that enable granting certificates (68\%), and providing conditions for self-learning (61\%). There are no specific actions introduced for talents that refer to remuneration, appraisal, or career planning. While designing TM, most of these companies consider employee expectations concerning motivational factors (90\%), promotion (87\%) and work organisation (84\%).

\section{C3: High Potential Internal Consultant / Organisation Development Facilitator ( $\mathrm{N}=\mathbf{3 0})$}

In this cluster, a talent can be someone who has above-average skills and abilities (50\%) and can have a significant impact on others (43\%). In $47 \%$ of these companies, there is a tendency to introduce TM sporadically, when the need arises. The most frequently introduced TM activities refer to appraisals (33\%) and career planning (33\%). To identify a talent among employees, these companies analyse appraisals that result from the previous few years (47\%). Moreover, these companies place information with the use of an intraorganisational information system (47\%) for the access of all employees. The SMEs that recruit talents place a job advertisement with very high requirements (57\% of cases) or use employee referrals (47\%). The most commonly used selection techniques are tasks that directly refer to a job position (47\%) and those that are not connected with their duties but enable a verification of candidates' potential (43\%). In most of these companies, a talented employee is responsible for coordinating tasks and specified functions or managing processes (53\%). There are tailored training programmes for talents introduced in most of these companies (83\%). These can focus on enhancing knowledge concerning the company as a whole (67\%) and developing managerial competences (40\%). To develop these competences, training conducted by internal specialists and trainers $(50 \%)$ or firmspecified training run by external consultants (40\%) may be offered. Generally, these companies do not differentiate between remuneration, appraisals, and career planning for talents. While designing TM, these firms usually take into account employee expectations concerning remuneration (93\%), motivational factors (80\%), and development (80\%).

\section{C4: High Potential Specialist / Process Leader $(\mathrm{N}=49)$}

In this cluster, a talented employee can be a person with a broad knowledge (57\%), aboveaverage skills (57\%), or an influence on others (45\%). Most companies run systematic TM activities available for all employees (53\%). The main activities included in TM are acquisition (65\%), identification (51\%), and training (49\%). To identify talents, SMEs may use previous yearly appraisals (59\%) or interviews with managers (59\%) aimed at finding employees who stand out. While attracting talents, these firms place advertisements in various media, which may set very high requirements (71\%) or use employee referrals (51\%). The selection process may use tasks not related to job specification (57\%), assessment centres 
(55\%), and tasks referring to job position (49\%). A talented person is responsible for fulfilling tasks that refer to a job position, but sometimes they are asked to take part in other processes (47\%). There may be training programmes tailored for talents $(57 \%)$, including internal trainings run by specialists or trainers $(55 \%)$ or coaching $(49 \%)$. These training programmes frequently aim at enhancing managerial competences (94\%). These companies introduce specified solutions that refer to remuneration (82\%). In comparison to other employees, talents often receive different salaries (47\%) or other forms of remuneration (39\%). Most SMEs in this cluster introduce specified appraisals (89\%), including different criteria (57\%) and evaluation tools (31\%). Almost all companies (96\%) match career paths to talents by introducing individualised plans (59\%) or taking into account talents' passions and interests (37\%). All of the SMEs (100\%) consider talents expectations concerning promotion and reassignment to other roles. Moreover, they may try to match talent expectations in work organisation (80\%) and motivational factors (74\%).

\section{C5: High Potential Manager $(\mathrm{N}=38)$}

In general, these companies perceive a talent as someone who is an above-average skilled (45\%) and highly qualified specialist (47\%). Most frequently, these companies run an inclusive, planned, and complex TM (47\%) that consists of talent acquisition (71\%), training (61\%), remuneration (47\%), appraisals (42\%), and career planning (42\%). To identify talents among employees, they may conduct interviews with supervisors or managers (aimed at finding employees who stand out; 58\%), analyse previous yearly appraisals (53\%), or check appraisal results from the previous few years (53\%). To attract talents, these SMEs place job advertisements in which they list very high requirements (66\%). They publish them in a profession related media (61\%). Moreover, half of the companies use employee referrals. In the selection process, they apply a wide range of techniques, such as interviews (76\%), job-related tasks (58\%), psychological tests (testing abilities; $58 \%)$, and analytical tests (50\%). In the majority of these SMEs, a talented employee is responsible for managing processes $(53 \%)$. There may be tailored training programmes introduced (55\%) aimed mostly at developing managerial competences. They include courses that grant certificates (61\%), firm-specific training conducted by external experts $(58 \%)$, case studies $(55 \%)$, training conducted by internal trainers or experts $(50 \%)$, and coaching (47\%). Most of these companies (87\%) differentiate the remuneration system for talents. Among $63 \%$ of these SMEs, a remuneration system refers to rewards and bonuses while, in $47 \%$, to remuneration forms. Furthermore, these may introduce different appraisal systems (84\%), which include some other criteria for evaluating performance (55\%), different methods (55\%), and parties involved (32\%); for example, they apply 360 degree feedback. Companies in this cluster provide talents with tailored career paths $(82 \%)$ and strive to meet talents' passions and interests (42\%). All of these companies take into account talents' expectations concerning reassignment to other roles, promotion, remuneration, and development. Moreover, SMEs gather opinions concerning motivational factors (95\%), career paths, and work organisation (87\%). 
Table 2. Main differences between clusters

\begin{tabular}{|c|c|c|c|c|c|c|}
\hline \multirow{3}{*}{ Criteria } & \multicolumn{6}{|c|}{ Clusters } \\
\hline & 1 & 2 & 3 & 4 & 5 & 6 \\
\hline & $\begin{array}{l}\text { High Performance } \\
\text { Manager }\end{array}$ & $\begin{array}{l}\text { High Performance } \\
\text { Specialist }\end{array}$ & $\begin{array}{l}\text { High Potential } \\
\text { Internal Consultant } \\
\text { / OD Facylitator }\end{array}$ & $\begin{array}{c}\text { High Potential } \\
\text { Specialist / Process } \\
\text { Leader }\end{array}$ & $\begin{array}{l}\text { High Potential } \\
\text { Manager }\end{array}$ & Creator \\
\hline Main talent indicator & Results & Results & $\begin{array}{l}\text { Skills and } \\
\text { knowledge }\end{array}$ & $\begin{array}{c}\text { Skills and } \\
\text { knowledge }\end{array}$ & $\begin{array}{c}\text { Skills and } \\
\text { knowledge }\end{array}$ & Creativity \\
\hline Main activities in TM & $\begin{array}{c}\text { Identification and } \\
\text { development }\end{array}$ & $\begin{array}{l}\text { Identification and } \\
\text { acquisition }\end{array}$ & $\begin{array}{l}\text { Appraisal and } \\
\text { development }\end{array}$ & $\begin{array}{c}\text { Identification and } \\
\text { development }\end{array}$ & All activities & Talent identification \\
\hline $\begin{array}{l}\text { Scope of talents } \\
\text { tasks and roles }\end{array}$ & $\begin{array}{c}\text { Mainly referring to } \\
\text { qualifications but } \\
\text { occasionally also } \\
\text { other }\end{array}$ & $\begin{array}{l}\text { Strictly connected } \\
\text { with tasks on a } \\
\text { given position }\end{array}$ & $\begin{array}{c}\text { Managing or } \\
\text { coordination of } \\
\text { tasks and processes }\end{array}$ & $\begin{array}{l}\text { Mainly referring to } \\
\text { qualifications }\end{array}$ & $\begin{array}{c}\text { Managing or } \\
\text { coordination of } \\
\text { tasks and processes }\end{array}$ & $\begin{array}{l}\text { Strictly connected } \\
\text { with tasks on a } \\
\text { given position }\end{array}$ \\
\hline $\begin{array}{l}\text { Main area of } \\
\text { development }\end{array}$ & $\begin{array}{c}\text { Managerial } \\
\text { competences }\end{array}$ & $\begin{array}{l}\text { Competences } \\
\text { related to tasks } \\
\text { fulfilment }\end{array}$ & $\begin{array}{l}\text { Competences } \\
\text { connected with } \\
\text { general } \\
\text { management and } \\
\text { firm functioning }\end{array}$ & $\begin{array}{c}\text { Managerial } \\
\text { competences }\end{array}$ & $\begin{array}{c}\text { Managerial } \\
\text { competences }\end{array}$ & $\begin{array}{l}\text { Mainly } \\
\text { competences } \\
\text { related to tasks } \\
\text { fulfilment }\end{array}$ \\
\hline
\end{tabular}

Source: own elaboration. 


\section{C6: Creator $(\mathrm{N}=22)$}

In this cluster, a talent is perceived mainly as a creative person able to implement modifications and innovations (46\%) or as a high performer (32\%). These companies tend to introduce TM sporadically whenever a need arises (36\%). They are usually focused on talent identification (64\%) mainly in the form of interviews with supervisors or managers (23\%). For attracting talents, these SMEs often place standard job advertisements in media (46\%) or publish job offers in profession- or branch-related magazines (41\%). In the selection procedures, they frequently apply screening (41\%) and standard job interviews (77\%). A talent is responsible mostly for fulfilling tasks that directly refer to their qualifications. These companies do not apply specific TM. They usually do not differentiate with regard to training programmes (73\% have the same for talents and other employees), remuneration (86\%), appraisal system (95\%), or career planning (96\%). Moreover, they do not take into account talent expectations while designing TM, as only $41 \%$ declare gathering opinions about remuneration.

The cluster characteristics presented above prove how differentiated TM in SMEs are. Although we identified six clusters, none is coherent enough to describe a common path for all SMEs it includes. A synthesis of TM characteristics in each cluster is presented in Table 2.

\section{DISCUSSION}

The research confirms that talent management in SMEs is executed in various ways and particular approaches significantly differ from others. However, on the basis of the data gathered, we may draw some similarities with regard to previous research, including those conducted in small, medium, and large enterprises.

According to Gallardo-Gallardo et al. (2013), talent is often equated to excellent performance or to unique or above-average skills and abilities, which refers to the idea of including high performers and high potentials into talent pool (Cappelli \& Keller, 2014). In our sample, only $5 \%$ of SMEs identify talents solely on the basis of performance, $31.5 \%$ on the basis of performance and competences, and $63.5 \%$ on the basis of above-average knowledge, skills, abilities, and attitudes. Such an approach may refer to the importance of human capital in building SMEs' competitive advantage (Patel \& Cardon, 2010; Razouk, 2011; Sheehan, 2014). Moreover, in companies that hire more than 250 employees, it is much easier to identify someone who stands out. Moreover, $27.5 \%$ of SMEs claim that talents can be engaged in fulfilling various tasks in organisations, and they are in general creative workers who introduce many improvements. This may refer to the findings of Valverde et al. (2013), who conclude that commitment and personal allegiance to the company plays an important role in SMEs.

Taking into account to whom TM is addressed, $34.5 \%$ of the companies take an exclusive and 33\% an inclusive approach, which refers to the model of lles et al. (2010) and confirms the findings of Valverde et al. (2013) who argue that both approaches appear among SMEs. Other companies claim that they introduce some actions when a need arises, without assuming whether all or only the chosen employees will be included. The majority of investigated SMEs (67.5\%) run TM continuously. This agrees with the findings of Festing et al. (2013), who distinguished approaches to TM in German SMEs into three 
clusters: "highly engaged talent management," "reactive talent management," and "retention-based talent management."

Employees to whom TM in SMEs is addressed occupy both managerial (45\%) and nonmanagerial (55\%) positions. Regardless of their position, $45 \%$ of companies claimed that talents coordinate the execution of specialised processes, act as experts in particular fields, or make use of their wide range of competences while performing diverse tasks. This may support the existence of a "position approach" to TM in SMEs (Collings \& Mellahi, 2009; Huselid \& Becker, 2011; Collings, 2014), according to which talents occupy pivotal positions.

By analysing the gathered data with the use of the "practices approach" - which perceives TM as the presence of key HR management practices (Collings \& Mellahi, 2009) - we may conclude that the investigated SMEs apply a diverse combination of activities. None of the companies introduced all of the practices referring to TM; that is, acquisition, identification, development, appraisal, remuneration, and career planning. Merely one out of four SMEs focus solely on talent acquisition and identification, $4.5 \%$ solely on development and career planning, while others apply a mix of practices aimed at retaining key employees. Thus, our findings confirm those of Festing et al. (2013) on clustering. Such a diversification in the scope of practices executed in SMEs, may stem from the lack of HR departments or specialists in SMEs. TM practices are developed and executed by managers or owners who frequently suffer from insufficient managerial skills (Price, 2004; Razouk, 2011; Pocztowski \& Pauli, 2013).

Valverde et al. (2013), on the basis of the research conducted in Spanish SMEs, concluded that, in general, SMEs apply the same HR systems to talented and non-talented personnel, although some distinction can be made. Our research confirms that more than half of the companies introduce some modifications in existing systems with regard to talented employees. $61.5 \%$ of SMEs apply development and remuneration systems crafted for talents, $59.5 \%$ evaluate talents in a different way, and $57.5 \%$ create distinct career plans. On the basis of these findings, we conclude that SMEs pay attention to managing their talented employees and perceive them as those who can significantly contribute to a firm's performance and outcomes.

The comparison between our findings and those presented by other researchers implies that most of the concepts that refer to TM can be traced in small and medium enterprises. However, due to the variety of their business models, their operational contexts, and the level of professional HR knowledge of managers or owners, they introduce unique approaches to TM based on combinations of approaches found within a vast array of literature.

\section{CONCLUSIONS}

On the basis of the conducted analysis, we infer that mapping TM patterns is easier in large companies, especially MNEs. There are specialists employed at HR departments in such organisations who aim to implement solutions and models perceived as effective. An example of such a model is PCMM (Curtis, Hefley, \& Miller, 2009) that precisely defines which tasks and actions should be undertaken. This results in the implementation of advanced processes of recruitment, development, appraisal, and remuneration, which are the foundations for introducing detailed tailored TM programmes. By contrast, HR management processes in SMEs are mostly run by managers or owners who 
may not possess adequate knowledge and skills to design TM. Additionally, the implementation of advanced HR management procedures can be costly and time-consuming - this causes it to be too costly for many SMEs. As a result, managers and owners may reduce spending on $\mathrm{HR}$ management, instead concentrating on the main scope of their business activities. Moreover, TM is strictly connected with the design of processes that refer to other functions in an enterprise. Thus, SMEs may develop different TM patterns, because they apply a variety of business models.

Our paper contributes to existing knowledge in two ways. Firstly, it is based on empirical research and provides readers with data gathered from 200 SMEs. As discussed above, we investigated TM in SMEs while there are only a few such studies based on empirical data. Secondly, we presented TM patterns in SMEs, which can be further modified and adjusted. These patterns describe potential approaches to TM in SMEs. Its variety proves the necessity to apply a contextual framework as this allows analysing TM processes with regard to the characteristics of SMEs (Joyce \& Slocum, 2012; Krishnan \& Scullion, 2017).

\section{Limitations}

The main limitation of the research relates to the structure and size of the sample. The research focused on a heterogeneous group of 200 SMEs. Narrowing the sample to more homogeneous enterprises could result in the identification of more internally similar clusters. Moreover, some other factors that determine the patterns of TM in SMEs could have been identified. In the sampling process we have asked a recruiting question concerning the implementation of any practices that refer to TM, and only those firms that confirmed it were included in the research. This could cause a possible bias as - according to Valverde et al. (2013) - some representatives of SMEs chose not to formally label their activities as TM. Thus, some valuable data that refers to TM in SMEs could not be captured. In our research, we applied only structured interviews; although this provided us with valuable information from managers and owners, it did not give us a deeper insight into detailed actions undertaken by SMEs. Thus, future studies should apply more detailed research that includes the analysis of documents and interviews with employees identified as talents.

Further study should enable the verification of the proposed patterns and praxis adjustment. Moreover, future scholars should verify if these patterns can be applied to SMEs other than Polish. Moreover, further research should focus on verifying which TM practices are the most effective. Such studies should evaluate the impact of TM on SME performance - which refers not only to financial indicators but also to those which are organisational, relational, and innovative in nature.

\section{REFERENCES}

Al Ariss, A., Cascio, W.F., \& Paauwe, J. (2014). Talent management: Current theories and future research directions. Journal of World Business, 49, 173-17. http://dx.doi.org/10.1016/j.jwb.2013.11.001

Barney, J.B. (1991). Firm resources and sustained competitive advantage. Journal of Management, 17(1), 99-120. https://doi.org/10.1177/014920639101700108

Becker, B.E., \& Huselid, M.A. (2006). Strategic human resource management: Where do we go from here?. Journal of Management, 32, 898-925. https://doi.org/10.1177/0149206306293668

Borkowska, S. (Ed.). (2005). Zarzqdzanie talentami. Warszawa: IPiSS. 
Boudreau, J.W., \& Ramstad, P.M. (2004). Talentship, talent segmentation, and sustainability: a new $\mathrm{hr}$ decision science paradigm for a new strategy definition. Human Resource Management, 44(2), 129-136.

Boxall, P., \& Macky, K. (2009). Research and theory on high-performance work systems: Progressing the high-involvement stream. Human Resource Management Journal, 19(1), 3-23. https://doi.org/10.1111/j.1748-8583.2008.00082.x

Boyatzis, R. (1982). The competent manager. New York: John Wiley and Sons.

Cappelli, P., \& Keller, J.R. (2014). Talent Management: Conceptual Approaches and Practical Challenges. Annual Review of Organisational Psychology, 1, 305-331. https://doi.org/10.1146/annurev-orgpsych-031413-091314

Cardon, M., \& Stevens, C.E. (2004). Managing human resources in small organisations: what do we know?. Human Resource Management Review, 14, 295-323. https://doi.org/10.1016/j.hrmr.2004.06.001

Collings, D.G., \& Mellahi, K. (2009). Strategic talent management: A review and research agenda. Human Resource Management Review, 19, 304-313. https://doi.org/10.1016/j.hrmr.2009.04.001

Collings, D.G. (2014). Toward Mature Talent Management: Beyond Shareholder Value. Human Resource Development Quarterly, 25(3), 301-319. https://doi.org/10.1002/hrdq.21198

Curtis, B., Hefley, B., \& Miller, S. (2009). People Capability Maturity Model Version 2.0. Retrieved from https://resources.sei.cmu.edu/asset_files/MaturityModule/2001_008_001_435287.pdf on February 15, 2019.

Deloitte (2017). Global Shared Services - 2017 Survey Report. Retrieved from https://www2. deloitte.com/content/dam/Deloitte/us/Documents/process-and-operations/us-globalshared-services-report.pdf on February 15, 2019.

Dries, N. (2013a). Talent management, from phenomenon to theory: introduction to special issue. Human Resource Management Review, 23, 267-271. http://dx.doi.org/10.1016/j.hrmr.2013.08.006

Dries, N. (2013b). The psychology of talent management: A review and research agenda. Human Resource Management Review, 23, 272-285. http://dx.doi.org/10.1016/j.hrmr.2013.05.001

Eurostat (2018). Retrieved from https://europa.eu/european-union/about-eu/figures/living_en\#tab-1-3 on February 15, 2019.

Festing, M., Harsch, L., Schäfer, L., \& Scullion, H. (2017). Talent management in Small- and MediumSized Enterprises. In D.G. Collings, K. Mellahi, \& W.F. Cascio (Eds.), Oxford Handbook of Talent Management (pp. 478-493). Oxford: Oxford University Press.

Festing, M., Schäfer, L., \& Scullion, H. (2013). Talent management in medium-sized German companies: An explorative study and agenda for future research. International Journal of Human Resource Management, 24(9), 1872-1893. http://dx.doi.org/10.1080/09585192.2013.777538

Gallardo-Gallardo, E., Dries, N., \& Gonzalez-Cruz, T.F. (2013). What is the meaning of 'talent' in the world of work?. Human Resource Management Review, 23, 290-300. http://dx.doi.org/10.1016/j.hrmr.2013.05.002

Gallardo-Gallardo, E., Thunnissen, M., \& Scullion, H. (2017). Special issue of International Journal of Human Resource Management. A contextualized approach to Talent Management: Advancing the field. International Journal of Human Resource Management, 1-4. https://doi.org/10.1080/09585192.2016.1275292

Hartigan, J.A., \& Wong, M.A. (1979). A k-means clustering algorithm. Journal of the Royal Statistical Society, 28(1), 100-108. https://doi.org/10.2307/2346830 
Huselid, M.A., \& Becker, B.E. (2011). Bridging micro and macro domains: Workforce differentiation and strategic human resource management. Journal of Management, 37, 421-428. https://doi.org/10.1177/0149206310373400

lles, P., Chuai, X., \& Preece, D. (2010). Talent management and HRM in multinational companies in Beijing: definitions, differences and drivers. Journal of World Business, 45(2), 79-89. https://doi.org/10.1016/j.jwb.2009.09.014

Ingram, T. (2016). Zarzqqdzanie talentami i pracownikami w dojrzałym wieku w kontekście wpływu na wyniki przedsiębiorstwa. Katowice: UE Katowice.

Ingram, T. (Ed.). (2011). Zarzqdzanie talentami. Warszawa, PWE.

Joyce, W.F., \& Slocum, J.W. (2012). Management Talent, strategic capabilities and firm performance. Organizational Dynamics, 41, 183-193. https://doi.org/10.1016/j.orgdyn.2012.03.001

Krishnan, T.N., \& Scullion, H. (2017). Talent management and dynamic view of talent in small and medium enterprises. Human Resource Management Review, 27, 431-441. http://dx.doi.org/10.1016/j.hrmr.2016.10.003

Lewis, R.E., \& Hackman, R.J. (2006). Talent management: A critical review. Human Resource Management Review, 16, 139-154. https://doi.org/10.1016/j.hrmr.2006.03.001

Listwan, T., Pocztowski, A., \& Stor, M. (2009). Managing Human Resources in Poland. In M.J. Morley, N. Heraty, \& S. Michailova (Eds.), Managing human resources in Central and Eastern Europe (pp. 90-131). Abingdon: Routledge.

Luna-Arocas, R., \& Morley, M.J. (2015). Talent management, talent mindset competency and job performance: the mediating role of job satisfaction. European Journal of International Management, 9(1), 28-51. https://doi.org/10.1504/EJIM.2015.066670

McDonnell, A., Collings, D.G., Mellahi, K., \& Schuler, R. (2017). Talent management: a systematic review and future prospects. European Journal of International Management, 11(1), 86-128. https://doi.org/10.1504/EJIM.2017.10001680

Miś, A. (2011). Talent Management. In A. Pocztowski (Ed.), Human Resource Management in Transition. The Polish Case (pp. 133-152). Warsaw: Wolter Kluwer Polska.

Morley, M., Poor, J., Heraty, N., Alas, R., \& Pocztowski, A. (2016). Developments in Human Resource Management in Central and Eastern Europe in Comparative Perspective. In M. Dickmann, C. Brewster, \& P. Sparrow (Eds.), International Human Resource Management - Contemporary Human Resource Issues in Europe (pp. 73-99). New York: Routledge.

Morley, M.J., Scullion, H., Collings, D.G., \& Schuler, R.S. (2015). Talent management: a capital question. European Journal of International Management, 9(1), 1-8. https://doi.org/10.1504/EJIM.2015.066668

Nijs, S., Gallardo-Gallardo E., Dries, N., \& Sels, L. (2014). A multidisciplinary review into the definition, operationalization, and measurement of talent. Journal of World Business, 49, 180-191. http://dx.doi.org/10.1016/j.jwb.2013.11.002

Patel, P.C., \& Cardon, M.S. (2010). Adopting HRM practices and their effectiveness in small firms facing product-market competition. Human Resource Management, 49(2), 265-290. https://doi.org/10.1002/hrm.20346

Pauli, U. (2015). In what to invest after surviving - the investment structure of growing SMEs. Journal of Entrepreneurship, Management and Innovation, 11(4), 93-114. https://doi.org/10.7341/20151144

Pocztowski A., \& Pauli U. (2013). Professionalization of HRM in SMEs. Zarzqdzanie Zasobami Ludzkimi (Human Resource management), 3-4, 9-22.

Pocztowski, A. (Ed.). (2008). Zarzq̨dzanie talentami w organizacji. Kraków: Wolters Kluwer Polska. 
Price, A. (2004). Human resource management in a business context. 2nd ed. London: Thomson Learning.

Rauch, A., \& Hatak, I. (2016). A meta-analysis of different HR-enhancing practices and performance of small and medium sized firms. Journal of Business Venturing, 31, 485-504. https://doi.org/10.1016/j.jbusvent.2016.05.005

Razouk, A.A. (2011). High-performance work systems and performance of French small-and medium-sized enterprises: Examining causal order. International Journal of Human Resource Management, 22(2), 311-330. https://doi.org/10.1080/09585192.2011.540157

Sandberg J., \& Pinnington, A.H. (2009). Professional Competence as Ways of Being: An Existential Ontological Perspective. Journal of Management Studies, 46(7), 1138-1170.

Scullion, H., Collings, D.G., \& Caliguiri, P. (2010). Introduction: Global talent management. Journal of World Business, 45(2), 105-108. https://doi.org/10.1111/j.1467-6486.2009.00845.x

Sheehan, M. (2014). Human Resource management and performance: Evidence from small and medium-sized firms. International Small Business Journal, 32(5), 545-570. https://doi.org/10.1177/0266242612465454

Skuza, A. (2018). Zarzqdzanie talentami a orientacja na uczenie się przedsiębiorstw. Poznań: Wydawnictwo UEP.

Skuza, A., Scullion H., \& McDonnell, A. (2013). An analysis of the talent management challenges in a post-communist country: the case of Poland. The International Journal of Human Resource Management, 24(3), 453-470, https://doi.org/10.1080/09585192.2012.694111

Sokołowski A., \& Czaja, M. (2014). Cluster separability and the effectiveness of k-means method. Research Papers of Wroclaw University of Economics, 237, 23-29.

Sparrow P.R., \& Makram, H. (2015). What is the value of talent management? Building value-driven process within a talent management architecture. Human Resource Management Review, 25, 249-263. http://dx.doi.org/10.1016/j.hrmr.2015.04.002

Spencer, L., \& Spencer, S. (1993). Competence at Work: Models for Superior Performance. New York: John Wiley \& Sons.

Tabor, J. (2013). Zarzq̨dzanie talentami w przedsiębiorstwie. Warszawa: Poltext.

Tarique, I., \& Schuler, R.S. (2010). Global talent management: Literature review, integrative framework, and suggestions for further research. Journal of World Business, 45(2), 122-133. https://doi.org/10.1016/j.jwb.2009.09.019

Thunnissen, M., Boselie, P., \& Fruytier, B. (2013). Talent management and relevance of context: Towards a pluralistic approach. Human Resource Management Review, 23, 326-336. http://dx.doi.org/10.1016/j.hrmr.2013.05.004

Vaiman, V., \& Holden, N.J. (2011). Talent management's perplexing landscape in Central and Eastern Europe. In: H. Scullion \& D.G. Collings (Eds), Global talent management (pp. 178193). London: Routledge.

Valverde, M., Scullion, H., \& Ryan, G. (2013). Talent management in Spanish medium-sized organisations. International Journal of Human Resource Management, 24(9), 1832-1852. https://doi.org/10.1080/09585192.2013.777545

Vlachos, I.P. (2009). The effects of human resource practices on firm growth. International Journal of Business Science and Applied Management, 4(2), 17-34.

Waters-Sobkowiak, M., Kowalski, T., \& Smits, S. (2018). The Evolving Potential of Talent Management in Poland. Entrepreneurial Business and Economics Review, 6(3), 159-174. https://doi.org/10.15678/EBER.2018.060310 
Westhead, P., \& Storey, D. (1996). Management training and small firm performance: Why is the link so weak?. International Small Business Journal, 14(4), 13-24. https://doi.org/10.1177/0266242696144001

\section{Authors}

The contribution share of authors is equal and amounted to $50 \%$ each of them.

\section{Urban Pauli}

PhD in Management, works at the Department of Human Capital Management at the Cracow University of Economics. His research interests cover issues of human capital management in small and medium enterprises, talent management, competency models, and human resource development. Correspondence to: Urban Pauli, PhD, Cracow University of Economics, Department of Human Capital Management, ul. Rakowicka 27, 31-436 Krakow, Poland, e-mail: urban.pauli@uek.krakow.pl ORCID (1) http://orcid.org/0000-0002-0196-451X

\section{Aleksy Pocztowski}

Professor and Chair of Human Capital Management Department at the Cracow University of Economics. Research interests: transformation of HR functions, strategic and international HR management, performance management, leadership, talent management, and diversity issues.

Correspondence to: Prof. Aleksy Pocztowski, Cracow University of Economics, Department of Human Capital Management, ul. Rakowicka 27, 31-436 Krakow, Poland, e-mail: aleksy.pocztowski@uek.krakow.pl

ORCID (1) http://orcid.org/0000-0001-7966-7251

\section{Acknowledgements and Financial Disclosure}

This paper was prepared as a part of project no. 2016/21/B/HS4/01593, "Talent Management in Small and Medium Enterprises," financed by the Polish National Science Center.

\section{Copyright and License}

This article is published under the terms of the Creative Commons

Attribution - NoDerivs (CC BY-ND 4.0) License

http://creativecommons.org/licenses/by-nd/4.0/

Published by the Centre for Strategic and International Entrepreneurship - Krakow, Poland 